\title{
Development of Interactive Media for the Basic Techniques of Multimedia-Based Badminton Games
}

\author{
${ }^{1}$ Luh Putu Tuti Ariani \\ Fakultas Olahraga dan Kesehatan \\ Universitas Pendidikan Ganesha \\ Buleleng, Indonesia \\ tuti.ariani@undiksha.ac.id
}

\author{
${ }^{2} \mathrm{Ni}$ Wayan Marti \\ Fakultas Teknik dan Keguruan \\ Universitas Pendidikan Ganesha \\ Buleleng, Indonesia \\ wayan-marti@undiksha.ac.id
}

\begin{abstract}
This study focused to produce interactive media for the basic techniques of multimedia-based badminton games. This research is a development research using the PPE development method. Design and Development research can be on front-end analysis Planning, Production, and Evaluation. The initial stage is a multimedia needs analysis. At the design stage, interactive media is designed by making storyboards. The development stage, interactive media is made using macromedia flash based on storyboards. The implementation stage, interactive media is tested on media experts and content experts. And in the evaluation stage, the media was improved based on the input of the two experts. The target of making this interactive media is the general public, for example students, university students, and prospective athletes who want to pursue badminton easily, fast and practical and the implementation can be done independently. This interactive media contains basic badminton basic techniques, which are grip types, stance, footwork, and all stroke techniques. Based on the results of trials on each of two media experts and content experts, it is stated that multimedia-based interactive media has very good quality, so that the product developed is suitable for use as a medium in the basic technical material for badminton games. This research produces a product in the form of multimedia-based interactive media in the form of an APK file that can be downloaded via the Play Store. Ready position (stance), leg movement (footwork), and all stroke techniques. Based on the results of trials on each of the two media experts and content experts, it is stated that multimedia-based interactive media has very good quality, so that the product developed is suitable for use as a medium in basic badminton game technical material. This research produces a product in the form of multimedia-based interactive media in the form of an APK file that can be downloaded via the Play Store. Ready position (stance), leg movement (footwork), and all stroke techniques. Based on the results of trials on each of the two media experts and content experts, it is stated that multimedia-based interactive media has very good quality, so that the product developed is suitable for use as a medium in basic badminton game technical material. This research produces a product in the form of multimedia-based interactive media in the form of an APK file that can be downloaded via the Play Store.
\end{abstract}

Keywords-basic badminton game techniques, development research, interactive media.

\section{INTRODUCTION}

Badminton is a sport which is very popular in Indonesian society and has become a mainstay sport in gaining achievements in the International world. The development of badminton, especially among the public and students, shows a very large number. The participation of badminton in every school can be seen in extracurricular who choose badminton and student activity units (UKM) so that it is clear that badminton has become popular in the community because it is in demand among elementary school students to high school, and even up to college.

Badminton is a sport played by two people for singles and two pairs for opposing doubles, like tennis, badminton is aimed at hitting the shuttlecock over the net so that it falls on the opponent's playing field, which has been determined and tries to prevent the opponent from counterattacking (Randi Nandika et al, 2017). This badminton game requires a racket as a bat, a shuttlecock that is used as an object that is hit. Badminton has the characteristics of various skills ranging from basic skills to the most complex skills. The goal of this sport is to get points and wins by crossing and dropping the shuttlecock on the opponent's playing field and trying to prevent the opponent from hitting the shuttlecock or dropping in the playing area itself (Fajar Ari Mangun, 2017). The development of badminton game has changed, it is packaged more attractively so that many countries have badminton athletes who excel. One of the changes is that the game uses game 21 and rally points, so it takes a shorter time than the previous game with game 15 . The effects of this game change according to people's views on the aspects that need to be developed in badminton training to the fullest. As a sport,badminton is a competitive sport, which requires explosive movements, lots of running movements, jumping, reflexes, speed changing directions, and also requires good eye-hand coordination (AndhegaWijaya, 2017). Apart from that, to become an accomplished badminton player requires mastery and understanding of physical, technical, tactical and psychological aspects effectively, efficiently and simultaneously. Basic technique is one type of skill that must be mastered and understood by every player in playing badminton (Tohar. 1991). Because it is one of the main supporters of sports achievement. The basic technique of playing badminton can be grouped into four parts, namely how to hold the racket (grips), ready stance (stance or ready position), footwork, and hitting or stroke motion (Subardjah et al., 2008).

In learning or practicing playing badminton, initial knowledge is needed so that the practice process is 
smoother. With current technological developments, it is necessary to make a media that can be used to facilitate and direct learning to play badminton. Multimedia that will be made is interactive which can be learnt independently. So far, badminton has been mostly done directly under the guidance of a coach. With this media development, the initial process can be carried out before going into the field or direct practice.This interactive multimedia is able to provide an understanding of the concept of movement earlier and can run more efficiently in helping and absorbing in depth and thoroughly the basic techniques of badminton. The use of interactive multimedia at this time has not fully provided comprehensive initial knowledge regarding the basic techniques of badminton so that the hope is in designing and making interactive media more fully and clearly. The current condition is that many people who like badminton do not yet to understand all the basic techniques of playing badminton.

In this research, researcher will design and create interactive media for the basic techniques of multimediabased badminton games. The target of this media is prospective athletes, students, students or the general public who are interested in exploring badminton

Referring to the background, the problem in this study is "How to design and develop interactive media on the basic techniques of multimedia-based badminton games?'The limitation of the problem of this research is interactive media based on multimedia, the media is stored on a DVD. The material discussed is the basic technique of racket handling, ready attitude, footwork (stepping movement), and punching techniques. The aim is to design interactive media for basic techniques of multimedia-based badminton games and to create interactive media for basic techniques of multimediabased badminton games. As well as the benefits of this research is as a complementary media in initial knowledge related to basic badminton game techniques and with this media it is able to learn more independently.

\section{RESEARCH METHODS}

This research is a type of PPE development research. According to Richey and Klein (2009) Design and Development Research can be on front-end analysis. Planning, Production, and Evaluation. This research basically aims to design and build interactive media for the basic techniques of multimedia-based badminton games. The research design is as follows: The first stage is to analyze the multimedia needs to be made. Based on the results of the multimedia needs, a story board design is made. The second stage of the development of the design results will be implemented using Flash media macro, the final stage is to conduct multimedia trials that have been made.

Research for the purpose of developing interactive multimedia basic badminton game techniques. This research is a type of development research. This development will be carried out at UNDIKSHA.

Data is a very important component in every study. With data, researcher can find out the state of the object under study. The data in this research will be collected by means of literature study, validation sheets, observation sheets, and questionnaires as described below.

(a) Data on stages of control and management processes, instructional design, development methods and other things related to the development of interactive media design for basic badminton game techniques.

(b) Data about didactic phenomena (realistic situations), user characteristics, and constraints in the use of interactive multimedia on basic badminton game techniques.

(c) Based on the results of items (1) and (2), the story board design was carried out and interactive multimedia was made of the basic badminton game techniques.

This research is a development research that used a type of prototypical studies, so that the data analysis must also refer to the data analysis techniques of similar research. Data about the control stages and didactic management process, user characteristics and constraints in the use of interactive multimedia, the basic techniques of manual badminton that exist will be analyzed by expert judgment.

In this study will produce interactive media products related to basic badminton game techniques that will be used by the general public who likes badminton as well as students, students and prospective athletes.

\section{RESULTS AND DISCUSSION}

Interactive media is an information media that discusses the basic techniques of badminton that are packaged in interactive multimedia. The target of this media is the general public, namely students, college students, prospective athletes ..

Interactive media is a media that presents material basic badminton techniques that aim to facilitate the process of introduction / initial knowledge of basic badminton techniques and be able to practice the basic badminton technique. Through this media, it is expected that the general public, namely students, students, and prospective athletes are able to perform basic badminton game techniques easily, in detail and practically because this media does not only present material about basic badminton game techniques, but is equipped with pictures and videos that explain the stages stages of doing basic badminton tactics

In making an interactive media, a design that can describe the content of each media page is needed, so that it is easy to understand when the media is used. To describe the flow of each media page a storyboard is made. With the existence of storyboard, it can make be easier to convey ideas that are owned to others, so that other people can produce the same perception as the ideas that were made before.

\section{A. Interactive Media Storyboard}

In making this interactive media an overview is needed to know the flow of each media page. The flow of each page is very helpful for editors to help organize each page according to predetermined ideas, so that it is easier, 
faster and more practical to make a storyboard. The following table is a storyboard from interactive media of basic badminton game techniques

Table 1. Media storyboard

\begin{tabular}{|c|c|c|c|c|}
\hline $\begin{array}{l}\mathbf{N} \\
\mathbf{0}\end{array}$ & $\begin{array}{l}\text { Visual } \\
\text { layer }\end{array}$ & $\begin{array}{l}\text { Navigation } \\
\text { Keys (TN) }\end{array}$ & $\begin{array}{l}\text { Informati } \\
\text { on }\end{array}$ & duration \\
\hline 1 & "It man a , & $\begin{array}{c}\text {-Contains no } \\
\text { navigati } \\
\text { on }\end{array}$ & $\begin{array}{l}\text { Media } \\
\text { intro with } \\
\text { opening } \\
\text { music }\end{array}$ & 8 seconds \\
\hline 2 & 8 & $\begin{array}{l}\text {-TN started } \\
\text {-TN Back } \\
\text {-TN Closed }\end{array}$ & $\begin{array}{l}\text { Clicking } \\
\text { the start } \\
\text { button will } \\
\text { go to the } \\
\text { initial } \\
\text { media } \\
\text { display }\end{array}$ & $\begin{array}{l}\text { Not } \\
\text { specified }\end{array}$ \\
\hline 3 &  & $\begin{array}{l}\text {-TN Back } \\
\text {-TN Closed } \\
\text {-TN Menu } \\
\text {-TN Sub } \\
\text { menu }\end{array}$ & $\begin{array}{l}\text { On this } \\
\text { page, there } \\
\text { are menus } \\
\text { and sub } \\
\text { menus for } \\
\text { each } \\
\text { material }\end{array}$ & $\begin{array}{l}\text { Not } \\
\text { specified }\end{array}$ \\
\hline 4 &  & $\begin{array}{l}\text {-TN Back } \\
\text {-TN Closed } \\
\text {-TN Menu } \\
\text {-TNSub } \\
\text { menu } \\
\text {-TN See } \\
\text { Photos } \\
\text {-TN Play } \\
\text { Videos }\end{array}$ & $\begin{array}{l}\text { On this } \\
\text { page there } \\
\text { is a menu } \\
\text { for viewing } \\
\text { photos and } \\
\text { playing } \\
\text { videos of } \\
\text { the } \\
\text { material } \\
\text { being } \\
\text { discussed }\end{array}$ & $\begin{array}{l}\text { Not } \\
\text { specified }\end{array}$ \\
\hline 5 & 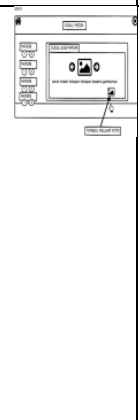 & $\begin{array}{l}\text {-TN Back } \\
\text {-TN Closed } \\
\text {-TN Menu } \\
\text {-TN Sub } \\
\text { menu } \\
\text {-TN See } \\
\text { Photos } \\
\text {-TN see }\end{array}$ & $\begin{array}{l}\text { on this } \\
\text { page will } \\
\text { display an } \\
\text { image of } \\
\text { the } \\
\text { material } \\
\text { described } \\
\text { along with } \\
\text { an } \\
\text { explanatio } \\
\mathrm{n} \text { of the } \\
\text { image } \\
\text { displayed }\end{array}$ & $\begin{array}{l}\text { Not } \\
\text { specified }\end{array}$ \\
\hline 6 & 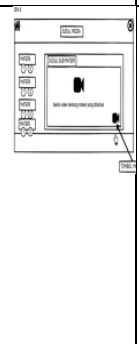 & $\begin{array}{l}\text {-TN Back } \\
\text {-TN Closed } \\
\text {-TN Menu } \\
\text {-TN Sub } \\
\text { menu } \\
\text {-TN See } \\
\text { Photos } \\
\text {-TN Play } \\
\text { video }\end{array}$ & $\begin{array}{l}\text { On this } \\
\text { page will } \\
\text { display a } \\
\text { video } \\
\text { about the } \\
\text { material } \\
\text { discussed }\end{array}$ & $\begin{array}{l}\text { Not } \\
\text { specified }\end{array}$ \\
\hline
\end{tabular}

The result of this development shows the appearance of an intro page with an opening animation containing the opening audio. The intro display has a duration of about 1 minute. Next will be displayed navigation page "Start" which means to start the media. Next will be displayed the main page containing 4 navigation menu buttons, namely the learning outcomes menu button, material menu, evaluation menu and buttons for the help menu.

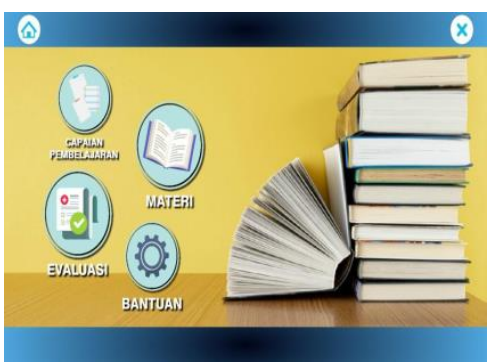

Picture. 1. Display Main Media Page

If the user clicks the learning outcomes menu button, a page will be displayed containing a description of the learning outcomes of this Badminton Coaching course. Clicking the material menu button will display an interactive media material page as shown in Figure

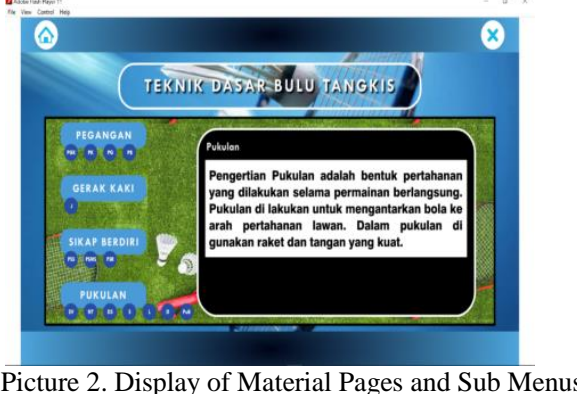

On this page view contains the material menu button, the sub menu button, the home button to return to the beginning which is at the top left of the display, the exit button which is at the top right of the display, the content section to display the content of each material / sub material. The menu navigation button consists of 4 menus, namely the handle material menu, the footwork material menu, the standing posture menu, and the punch material menu. The content section is also equipped with navigation buttons to display material which contains the stages in practicing sub-material related to the menu, and navigation buttons to display practical videos.

\section{B. Media Validation}

The validation of this interactive media was carried out by three experts in their fields. The validation was carried out on 3 things, namely the content / content of the badminton game material, the technical operation of the interactive media and the presentation of the material in this interactive media (Rahmatan, et al, 2012). In addition to providing an assessment, at the end of the validation sheet there is space for notes to provide additional input that was not yet available on the previous question items. The questions and answers given by each expert are shown in Tables 2, 3 and 4.

Table 2. Badminton Material / Content Validation

\begin{tabular}{|l|c|c|c|c|c|l|}
\hline \multirow{2}{*}{ Statement } & \multicolumn{3}{|c|}{ Score } & \multirow{2}{*}{ Average } & Percentage & Criteria \\
\cline { 2 - 4 } & A1 & A2 & A3 & & \\
\hline $\begin{array}{l}\text { Truth of } \\
\text { Concept }\end{array}$ & 5 & 5 & 4 & 4.67 & 93 & Good \\
\hline $\begin{array}{l}\text { Depth of } \\
\text { Concept }\end{array}$ & 5 & 4 & 4 & 4.33 & 87 & Good \\
\hline $\begin{array}{l}\text { Power of } \\
\text { Concept }\end{array}$ & 5 & 5 & 5 & 5.00 & 100 & $\begin{array}{l}\text { Very } \\
\text { Good }\end{array}$ \\
\hline
\end{tabular}




\begin{tabular}{|l|c|c|c|c|c|c|}
$\begin{array}{l}\text { Practicing } \\
\text { how to } \\
\text { complete an } \\
\text { exercise }\end{array}$ & 5 & 5 & 5 & 5.00 & 100 & $\begin{array}{l}\text { Gery } \\
\text { GOod }\end{array}$ \\
\hline $\begin{array}{l}\text { Presentation } \\
\text { Structure }\end{array}$ & 4 & 4 & 5 & 4.33 & 87 & Good \\
\hline $\begin{array}{l}\text { Serving } \\
\text { Flow }\end{array}$ & 4 & 4 & 4 & 4.00 & 80 & Good \\
\hline $\begin{array}{l}\text { Written } \\
\text { Language }\end{array}$ & 4 & 4 & 4 & 4.00 & 80 & Good \\
\hline $\begin{array}{l}\text { Narrative } \\
\text { Language }\end{array}$ & 4 & 5 & 4 & 4.33 & 87 & Good \\
\hline
\end{tabular}

problem solving exercises. Among the notes at the end of the badminton material validation sheet, there is a revision in the form of adding a resume on the material that has been studied. The additions are summarized in one screen before the lesson ends. Table 3 shows that technically the operation contained in interactive media is appropriate both in terms of link navigation, response responses and interactivity. However, in terms of convenience for users, it is relatively easy because if users

Information:

* The scores are in the interval $1-5$, with A1 = Expert $1, \mathrm{~A} 2=$ Expert 2 , and $\mathrm{A} 3=$ Expert3

** Criteria: 1-1.9 (Very Poor), 2-2.9 (Poor), 3-3.9 (Enough), 4-4.9 (Good), 5 (Very Good) difficulty. And if users have done 2 or 3 frames in answering the question then the next it will be easy for the user. Table 4 shows that the presentation of the material contained in interactive media is appropriate both in terms of clarity, relevance, results and follow-up.

Table 3. Validation of Interactive Media Operation Techniques

\begin{tabular}{|l|c|c|c|c|c|l|}
\hline \multirow{2}{*}{ Statement } & \multicolumn{3}{|c|}{ Score } & \multirow{2}{*}{$\begin{array}{c}\text { Averag } \\
\text { e }\end{array}$} & $\begin{array}{c}\text { Percentag } \\
\text { e }\end{array}$ & $\begin{array}{c}\text { Criteri } \\
\text { a }\end{array}$ \\
\cline { 2 - 5 } & $\begin{array}{c}\text { A } \\
\text { 1 }\end{array}$ & $\mathbf{A 3}$ & & & \\
\hline $\begin{array}{l}\text { Menu and } \\
\text { submenu } \\
\text { links }\end{array}$ & 5 & 5 & 5 & 5.00 & 100 & $\begin{array}{l}\text { Very } \\
\text { Good }\end{array}$ \\
\hline Navigation & 5 & 5 & 5 & 5.00 & 100 & $\begin{array}{l}\text { Very } \\
\text { Good }\end{array}$ \\
\hline Help & 4 & 4 & 3 & 3.67 & 73 & Enough \\
\hline $\begin{array}{l}\text { Choice of } \\
\text { answers to } \\
\text { questions }\end{array}$ & 3 & 4 & 4 & 3.67 & 73 & Enough \\
\hline $\begin{array}{l}\text { Media } \\
\text { elements }\end{array}$ & 5 & 5 & 5 & 5.00 & 100 & $\begin{array}{l}\text { Very } \\
\text { Good }\end{array}$ \\
\hline Interactivity & 5 & 5 & 5 & 5.00 & 100 & $\begin{array}{l}\text { Very } \\
\text { Good }\end{array}$ \\
\hline $\begin{array}{l}\text { Creative } \\
\text { Convenienc } \\
\text { e for users }\end{array}$ & 5 & 5 & 4 & 4.33 & 87 & $\begin{array}{l}\text { Very } \\
\text { Good }\end{array}$ \\
\hline
\end{tabular}

\section{CONCLUSION}

The results of validation by experts can be concluded that interactive media is appropriate both in terms of badminton material content, technical operations and presentation of material in this interactive media. Therefore, it can be used for badminton coaching learning after making several revisions according to expert suggestions and input for the perfection of the learning program.

This interactive media is a tool used to clearly understand the initial knowledge of the basic badminton game techniques, which provides detailed explanations, pictures, videos and dubs. This interactive media also provides information effectively so that the desired goals can be achieved properly and perfectly. The development of this interactive media helps to make it easier and to master and practice the basic techniques of badminton independently. This interactive media product was developed through reviews fromexperts in badminton game content / content, technical operation of interactive media and presentation of material in interactive media, developed media can be accepted and suitable for use. In the use of interactive media, it is necessary to socialize how to use interactive media so that the general public understands the functions and uses of interactive media and how to operate them correctly and appropriately.

\section{REFERENCES}

Alessi, S. M., \& Trollip, S. R. (2001). Multimedia for learning: Methods and development. Allyn \& Bacon.

Wijaya, A. (2017). Analisis gerak keterampilan servis dalam permainan Bulutangkis (suatu tinjauan anatomi, fisiologi, dan biomekanika). Indonesia Performance Journal, 1(2), 106111.

Tarigan, D., \& Siagian, S. (2015). Pengembangan Media Pembelajaran Interaktif Pada Pembelajaran Ekonomi. Jurnal Teknologi Informasi \& Komunikasi dalam Pendidikan, 2(2).

Kurniawati, I. D. (2018). Media pembelajaran berbasis multimedia interaktif untuk meningkatkan Pemahaman konsep mahasiswa. DoubleClick: Journal of Computer and Information Technology, 1(2), 68-75.

Information:

* The scores are in the interval $1-5$, with $\mathrm{A} 1=$ Expert $1, \mathrm{~A} 2=$

Expert2, and A3 = Expert3

** Criteria: 1-1.9 (Very Poor), 2-2.9 (Poor), 3-3.9 (Enough), 4-4.9

(Good), 5 (Very Good)

Table 2 shows that conceptually the material contained in interactive media is appropriate both in terms of material depth, material presentation structure and 
Nandika, R., Hadi, D. T., \& Ridho, Z. A. (2017). Pengembangan Model

Latihan Strokes Bulutangkis Berbasis Footwork Untuk

Anak Usia Pemula (U-15). Gladi: Jurnal Ilmu

Keolahragaan, 8(2), 102-110.

Sugiyono, P. D. (2010). Metode penelitian pendidikan. Pendekatan

Kuantitatif.

Sutopo, H. (2008). Pengembangan Bahan Ajar Berbasis Multimedia.

Tersedia: http://www. topazart.

info/teks_teaching/mat/flash/tutorialBahanAjar

Multimedia. Pdf..

Tohar.1991.“OlahragaPilihanBulutangkis.Departemen Pendidikan dan Kebudayaan. Direktorat Jenderal Pendidikan Tinggi.

Jakarta. Proyek pembinaan Tenaga kependidikan

Zarwan, Z., Arsil, A., \& Hardiansyah, S. (2018). Studi Tentang Kemampuan Teknik Dasar Bulutangkis Siswa Sekolah Dasar. MAJALAH ILMIAH, 25(2). 